\title{
Pengaruh Penerapan Sistem Manajemen Mutu ISO 9001:2008 terhadap Kinerja Karyawan
}

\author{
Vivi Novdya Limbong and Adi Irawan ${ }^{\mathrm{b}, *}$ \\ aManajemen Bisnis, Politeknik Negeri Batam, vivinovdya@gmail.com, Indonesia \\ ${ }^{a}$ Manajemen Bisnis, Politeknik Negeri Batam, adiirawan@polibatam.ac.id, Indonesia
}

\begin{abstract}
Quality standart has became the fundamental parameter for the perfection of every product. Human resource is a valuable assets for the productive company that the quality standart it held should be clearly elaborated to maintain the quality and the work performance remains effective. The following research aims to review how the ISO 9001:2008 quality management system affects the employee's work performance. The 52 respondents of this research consist of production managers and human resource department employees of electricity and elecrtronic companies at Batamindo Muka Kuning, Batam. Data analyzing method used for this research is a simple analytical regression. The research results that the application of ISO 9001:2008 quality management system is effectively affects the employee's performance which goes as the ISO 9001:2008 quality standart procedure. According to the result, it is vital for the company to ensure the continuance of socialization to the whole employee in order to avoid any possible human errors, and to maintain the costumer satisfaction. This research verges on production manager and HRD division of electricity and electronic company at Batamindo Muka Kuning, Batam, therefore, it suggest for the next further research to use the sample from the other company or another district.
\end{abstract}

Keywords: quality management system, iso 9001:2008, employee performance

\section{Pendahuluan}

Setiap perusahaan tentunya berkeinginan mendapat keuntungan yang optimum, oleh karena itu perusahaan juga harus mampu memberdayakan seluruh sumber daya yang dimiliki untuk dapat digunakan secara optimum pula. Realita di lapangan menunjukkan bahwa perusahaan yang maju dan dapat bertahan dalam ketatnya persaingan adalah perusahaan yang memiliki kinerja karyawan yang handal dan diakui dalam dunia perindustrian baik di tingkat nasional maupun internasional. Beberapa perusahaan yang sudah sukses menyadari bahwa pada dasarnya peningkatan bisnis mereka dilandasi oleh suatu sistem yang dilaksanakan secara konsisten dan efisien sehingga menghasilkan kinerja perusahaan yang lebih baik. Sistem tersebut perlu dituliskan dan didokumentasikan sehingga karyawan dapat mengetahui sasaran dan hal apa yang diharapkan oleh perusahaan. Pola pelaksanaan secara konsisten tersebut merupakan prinsip dalam melaksanakan manajemen mutu (Dharma, 2007).

Perhatian yang begitu besar terhadap masalah kinerja dapat dipahami karena menyangkut efisiensi dan efektifitas penggunaan sumber daya manusia dalam mencapai tujuan yang telah ditetapkan oleh suatu organisasi. Suastha mengatakan bahwa baik buruknya kinerja seorang karyawan dapat dilihat dari keterkaitan pekerjaan yang dilakukan, dengan misi atau sasaran organisasi. Sistem manajemen mutu ISO 9001:2008 diberlakukan sebagai suatu pencapaian hasil yang dilakukan oleh manajemen perusahaan yang diharapkan mampu membawa dampak yang baik bagi kelangsungan kinerja karyawan di perusahaan mengingat keberhasilan pelaksanaan sistem manajemen mutu ISO bergantung pada kinerja karyawan sebagai pondasi berjalannya suatu organisasi. Rumusan masalah dalam penelitian ini

\footnotetext{
*Corresponding author. E-mail: adiirawan@polibatam.ac.id
} 
adalah apakah penerapan sistem manajemen mutu ISO 9001:2008 berpengaruh terhadap kinerja karyawan pada perusahaan elektronik dan elektrik yang telah menerapkan sistem manajemen mutu ISO 9001:2008 di kawasan industri Batamindo, Muka Kuning, Batam. Penelitian ini memiliki tujuan untuk menguji pengaruh penerapan sistem manajemen mutu ISO 9001:2008 terhadap kinerja karyawan pada perusahaan elektronik dan elektrik di kawasan industri Batamindo, Muka Kuning, Batam yang telah menerapkan sistem manajemen mutu ISO 9001:2008.

\section{Kajian Literatur}

\section{Teori deming}

Teori Deming memberikan suatu siklus yang disebut dengan siklus Deming. Siklus Deming adalah model perbaikan berkesinambungan yang terdiri atas empat komponen utama secara berurutan yang dikenal dengan siklus PDCA (Plan-Do-Check-Act). Siklus ini dikembangkan untuk menghubungkan antara operasi dengan kebutuhan pelanggan dan memfokuskan sumber daya semua bagian dalam perusahaan (riset, desain, operasi, dan pemasaran) untuk memenuhi kebutuhan pelanggan.

\section{Teori juran}

Juran mendefinisikan kualitas sebagai fitness for use, yang mengandung pengertian bahwa suatu barang atau jasa harus dapat memenuhi apa yang diharapkan oleh para pemakainya. Kontribusi Juran adalah Juran's Basic Steps to Progress, diantaranya: Mencapai perbaikan terstruktur atas dasar berkesinambungan yang dikombinasikan dengan dedikasi dan keadaan yang mendesak, mengadakan program pelatihan secara luas, membentuk komitmen dan kepemimpinan pada tingkat manajemen yang lebih tinggi.

\section{Teori crosby}

Manajemen kualitas menurut Crosby adalah definisi kualitas memenuhi atau sama dengan persyaratan, sistem kualitas adalah pencegahan adalah sebaiknya dilakukan pencegahan dari awal sehingga outputnya dijamin bagus serta hemat biaya dan waktu, tidak memiliki kerusakan merupakan standar kinerja yang harus digunakan dan dapat tercapai apabila perusahaan melakukan sesuatu yang benar sejak pertama proses dan setiap proses.

\section{Teori dua faktor herzberg}

Teori ini disebut juga teori motivasi higiene yang dikemukakan oleh seorang psikolog bernama Frederick Herzberg. Dengan keyakinan bahwa hubungan seorang individu dengan pekerjaan adalah mendasar dan bahwa sikap seorang terhadap pekerjaan dapat dengan sangat baik menentukan keberhasilan atau kegagalan. Hubungan antara Teori Dua Faktor Herzberg dan penelitian ini dilihat dari sisi kinerja. Melalui cara individu bersikap baik dan menghargai pekerjaannya akan mendorong tercapainya suatu hasil yang diinginkan dan sebaliknya apabila individu bersikap tidak baik dan tidak menghargai pekerjaannya maka akan sulit untuk mencapai tujuan yang diinginkan. Memanfaatkan sumber daya manusia mengandung pengertian pembinaan struktur organisasi dan pengembangan mutu tenaga kerja baik secara aktual maupun potensial.

Kinerja tidak hanya merupakan produktivitas karena kinerja menyangkut perilaku alami yang dimiliki seseorang untuk bebas melakukan tindakan sesuai keinginannya, perilaku bebas untuk bertindak ini tetap tidak bisa dilepaskan dari syarat-syarat formal peran seorang karyawan untuk meningkatkan fungsi efektif suatu organisasi (Rahman, 2008). Kinerja adalah penampilan kerja secara kualitas dan kuantitas yang disuguhkan oleh seorang pegawai dalam melaksanakan tugasnya sesuai dengan tanggung jawab yang diberikan. Kinerja dapat dilihat dari segi kecakapan, keterampilan, pengetahuan dan kesungguhan pegawai yang bersangkutan. Kinerja merupakan kondisi yang harus diketahui dan diinformasikan kepada pihak-pihak tertentu untuk mengetahui tingkat pencapaian hasil suatu instansi dihubungkan dengan visi yang diemban suatu organisasi serta mengetahui dampak positif dan negatif suatu kebijakan operasional yang diambil (Chasanah, 2008).

\section{Sistem manajemen mutu}

Sistem manajemen mutu (SMM) merupakan suatu sistem manajemen untuk mengendalikan dan mengarahkan organisasi dalam hubungannya dengan mutu. Sistem manajemen mutu merupakan sekumpulan prosedur terdokumentasi dan praktekpraktek standar untuk manajemen sistem yang bertujuan menjamin kesesuaian dari suatu proses dan produk terhadap kebutuhan atau persyaratan tertentu. 


\section{Kinerja}

Memanfaatkan sumber daya manusia mengandung pengertian pembinaan struktur organisasi dan pengembangan mutu tenaga kerja baik secara aktual maupun potensial. Kinerja tidak hanya merupakan produktivitas karena kinerja menyangkut perilaku alami yang dimiliki seseorang untuk bebas melakukan tindakan sesuai keinginannya, perilaku bebas untuk bertindak ini tetap tidak bisa dilepaskan dari syaratsyarat formal peran seorang karyawan untuk meningkatkan fungsi efektif suatu organisasi (Rachman, 2008). Pengertian kinerja adalah penampilan kerja secara kualitas dan kuantitas yang disuguhkan oleh seorang pegawai dalam melaksanakan tugasnya sesuai dengan tanggung jawab yang diberikan. Kinerja dapat dilihat dari segi kecakapan, keterampilan, pengetahuan dan kesungguhan pegawai yang bersangkutan.

\section{Hipotesis}

Penerapan sistem manajemen mutu ISO 9001:2008 diharapkan dapat membantu karyawan bekerja dengan lebih jelas dan terstandarisasi dengan baik karna sudah ada panduan yang jelas. Hal tersebut didukung oleh penelitian Baird, Hu, Reeve (2011), Dharma (2007), dan Rachman (2008) menemukan bahwa penerapan sistem manajemen mutu ISO 9001:2008 berpengaruh terhadap kinerja karyawan. Berdasarkan hubungan antar variabel tersebut, maka diajukan:

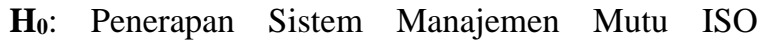
9001:2008 memiliki pengaruh terhadap kinerja karyawan.

Ha: Penerapan Sistem Manajemen Mutu ISO 9001:2008 tidak memiliki pengaruh terhadap kinerja karyawan.

\section{Metode Penelitian}

\section{Instrumen penelitian dan operasional variabel}

Instrumen dalam penelitian ini adalah data primer yaitu jenis data yang diperoleh secara langsung dari responden melalui wawancara (tanya jawab) dan survei. Jenis data yang akan dikumpulkan adalah data ordinal. Instrumen pertanyaan menggunakan skala Likert 5 poin dengan pemberian bobot nilai pada masing-masing poin, yaitu: sangat setuju (nilai 5), setuju (nilai 4), ragu-ragu (nilai 3), tidak setuju (nilai 2), dan sangat tidak setuju (nilai 1) untuk setiap jawaban responden dari masing-masing pernyataan penelitian. Data sekunder merupakan pelengkap data primer yang diperoleh dari bagian information resources centre di Batamindo, dan juga diperoleh dari situs web resmi di internet, buku-buku, dan sumber lainnya yang erat kaitannya dengan sistem manajemen mutu ISO 9001:2008 dan kinerja karyawan. Variabel independen sistem manajemen mutu ISO 9001:2008 diukur dari dampaknya terhadap kinerja karyawan. Variabel dependen kinerja karyawan diukur dari dimensi apakah setiap responden selalu mengerjakan pekerjaannya sesuai dengan standar mutu perusahaan.

\section{Populasi, sampel dan teknik penarikan sampel}

Populasi dalam penelitian ini adalah manajer produksi dan manajer $H R D$ yang bekerja pada perusahaan elektrik dan atau elektronik di kawasan industri Batamindo, Muka Kuning, Batam yang berjumlah 52 orang. Jumlah sampel adalah sebanyak 52 responden dengan arti bahwa menggunakan seluruh populasi yang ada yang ditetapkan dengan menggunakan tabel Krejcie dan Morgan.

\section{Validitas dan reliabilitas instrumen}

Butir pernyataan kuesioner dinyatakan valid jika nilai $r$ hitung $>$ r tabel, dengan $r$ tabel $=0,279$.

Tabel 1

Uji Validitas

\begin{tabular}{lc}
\hline \multicolumn{1}{c}{ Variabel } & r hitung \\
\hline Variabel SMM ISO 9001:2008 & \\
Pertanyaan 1 & 0,585 \\
Pertanyaan 2 & 0,424 \\
Pertanyaan 3 & 0,765 \\
Pertanyaan 4 & 0,547 \\
Pertanyaan 5 & 0,765 \\
Pertanyaan 6 & 0,557 \\
Pernyataan 7 & 0,496 \\
Pernyataan 8 & 0,857 \\
Pernyataan 9 & 0,322 \\
Pernyataan 10 & 0,582 \\
Pernyataan 11 & 0,667 \\
Pernyataan 12 & 0,747 \\
Pernyataan 13 & 0,747 \\
Pernyataan 14 & 0,296 \\
& \\
Variabel Kinerja & \\
Pertanyaan 1 & 0,609 \\
Pertanyaan 2 & 0,432 \\
Pertanyaan 3 & 0,565 \\
Pertanyaan 4 & 0,738 \\
Pertanyaan 5 & 0,522 \\
Pertanyaan 6 & 0,545 \\
Pertanyaan 7 & 0,550 \\
\hline
\end{tabular}




\begin{tabular}{ll}
\hline Pertanyaan 8 & 0,465 \\
Pertanyaan 9 & 0,418 \\
Pertanyaan 10 & 0,421 \\
Pertanyaan 11 & 0,784 \\
\hline
\end{tabular}

Dapat dilihat pada Tabel 1 bahwa semua butir pertanyaan yang digunakan dinyatakan valid karena memiliki nilai $r$ hitung $>r$ tabel.

Tabel 2

Uji Reliabilitas

\begin{tabular}{lc}
\hline \multicolumn{1}{c}{ Variabel } & alpha-Cronbach \\
\hline Variabel Sistem Manajemen Mutu ISO & 0,863 \\
Variabel Kinerja & 0,761 \\
\hline
\end{tabular}

Butir pernyataan kuesioner dalam penelitian ini dinyatakan reliabel karena nilai alpha-Cronbach masing-masing variabel penelitian, yang ditunjukkan pada Tabel 2, lebih besar dari 0,70.

\section{Pembahasan}

Data dianalisis dengan menggunakan SPSS versi 20.0. Uji regresi sederhana digunakan untuk menganalisis bagaimana pengaruh penerapan sistem manajemen mutu ISO 9001:2008 terhadap kinerja karyawan. Penelitian ini menggunakan uji regresi sederhana untuk menguji pengaruh satu variabel bebas atau variabel independen terhadap variabel terikat atau variabel dependen. Regresi sederhana terdiri dari satu variabel bebas sebagai predictor dan satu variabel terikat sebagai respon, dengan persamaan:

$Y=a+b X$

Keterangan:

Y : Variabel terikat

a : Konstanta regresi

bX : Nilai turunan atau peningkatan variabel bebas

Pengambilan keputusan dalam uji regresi sederhana yang digunakan adalah dengan membandingkan nilai Sig. dengan nilai probabilitas 0,05 . Jika nilai Sig. tidak lebih besar dari nilai probabilitas, artinya variabel bebas secara signifikan berpengaruh terhadap variabel terikat. Jika nilai Sig. lebih besar dari nilai probabilitas, artinya variabel bebas tidak berpengaruh signifikan terhadap variabel terikat.

Berdasarkan Tabel 3, variabel sistem manajemen mutu ISO 9001:2008 memiliki nilai signifikansi lebih kecil dari 0,05, maka disimpulkan bahwa penerapan sistem manajemen mutu ISO 9001:2008 berpengaruh terhadap kinerja, sehingga $\mathrm{H}_{\mathrm{o}}$ diterima.

Tabel 3

Uji Regresi Sederhana

\begin{tabular}{ccc}
\hline Variabel & t & Sig. \\
\hline Sistem Manajemen Mutu ISO & 8,232 & 0,000 \\
\hline
\end{tabular}

\section{Kesimpulan}

Berdasarkan hasil penelitian mengenai pengaruh penerapan sistem manajemen mutu ISO 9001:2008 dan kinerja karyawan pada karyawan yang bekerja di perusahaan elektrik dan elektronik dapat ditarik kesimpulan sesuai dengan perumusan masalah yaitu bahwa penerapan sistem manajemen mutu ISO 9001:2008 berpengaruh terhadap kinerja karyawan yang bekerja di perusahaan elektronik dan elektrik di kawasan industri Batamindo muka kuning Batam. Penerapan sistem manajemen mutu ISO dapat membuat karyawan bekerja dengan lebih jelas dan terstandarisasi dengan baik karna sudah ada panduan yang jelas. Perusahaan dalam hal ini diharapkan dapat terus menanamkan nilai-nilai standar mutu sesuai dengan delapan klausul ISO 9001:2008 dan mampu untuk mempertahankan mutu dan standar yang baik. Perusahaan diharapkan dapat terus memperhatikan juga mempertahankan kinerja karyawan yang baik sehingga perusahaan mendapatkan hasil yang optimal dari produk yang dihasilkan.

Penelitian ini memiliki keterbatasan, diantaranya: obyek penelitian adalah seorang manajer yang sangat sibuk dalam pekerjaannya dan jarang berada di kantor sehingga sulit untuk bertemu dan melakukan wawancara, sehingga wawancara dilakukan kepada perwakilannya tidak langsung kepada obyek penelitian. Obyek penelitian terbatas yaitu hanya pada perusahaan elektronik dan elektrik. Wilayah penelitian juga masih sangat terbatas hanya pada satu lokasi saja yaitu Batamindo, Muka Kuning. Saran untuk penelitian selanjutnya untuk menyusun waktu untuk dapat bertemu dengan manajer dan melakukan wawancara langsung, disarankan dapat menambahkan variabel baru untuk melihat pengaruh variabel lain terhadap kinerja karyawan dan disarankan juga dapat menambah sampel penelitian selain perusahaan elektronik dan elektrik atau tetap menggunakan jenis perusahaan yang sama, namun diterapkan di daerah lain karena perbedaan budaya dan lingkungan di masing-masing daerah dapat mempengaruhi hasil penelitian. Selain itu penelitian selanjutnya juga dapat 
memperluas wilayah obyek penelitian, tidak hanya terbatas pada satu kawasan industri saja.

\section{References}

Baird, K., Hu, K. J., \& Reeve, R. (2011). The Relationships between Organizational Culture, Total Quality Management Practices and Operational Performance. International Journal of Operations \& Production Management, 31(7), 789-814.
Chasanah, N. (2008). Analisis Pengaruh Empowerment, Self Efficacy dan Budaya Organisasi terhadap Kepuasan Kerja dalam Meningkatkan Kinerja Karyawan (Studi Empiris pada Karyawan PT. Mayora Tbk Regional Jateng dan DIY).

Dharma, C. (2007). Analisis Pengaruh Penerapan Sistem Manajemen Mutu ISO 9001:2000 terhadap Peningkatan Kinerja Pada PT Jasa Raharja (Persero) Cabang Sumatera Utara.

Rachman, R. (2008). Analisis Penerapan Sistem Manajemen Mutu ISO 9001:2000 dalam Menunjang Total Quality Management pada Divisi Infratel di PT. TELKOM. 